\title{
Religiosity in Multimodality: A Case Study of Wardah Advertisement
}

\author{
Levinda Hesty Suryawardhani, Universitas Airlangga
}

\begin{abstract}
The shift of key factors affecting consumer behaviour in emerging markets from economic, social and politic to religion based consumption has expanded the territory of halal industry which was formerly and solely limited to food to now cover the concept of halal for non-food industry including cosmetics industry that currently lives up to all the type. The manifestation of faith issue has forced marketers as well as advertisers to formulate a thriving strategy of specific branding and advertising techniques for specific market segment i.e. Muslim consumers that aggressive to modern consumption yet sensitive to faith value. The present paper attempts to investigate the verbal and visual elements of halal cosmetics advertising and the relationship of the multimodal elements to discover the attitude of advertising textual and visual markers in guiding the consumers understand the cosmetic manufacturers' product advertised. The current paper is preceded by the review of pertinent literature regarding the compelling factors influencing the cosmetic consumer purchase intention, yet little study researches advertisement as one of the potential factors. Adopting Cheong's (2004) multimodal framework and Royce's (1998) Intersemiotic framework, the finding suggests that the use of verbal markers are coupled with visual signs of the advertisement to generate the religious ideology promoted by the halal cosmetics advertisement.
\end{abstract}

Keywords: cosmetics advertisement; halal advertisement; wardah advertisment

\section{Introduction}

Approaching the free trade era, the global market has become extremely fierce. Thus, in order to compete globally in the international market, producers as well as marketers has been compelled to achieve breakthrough and innovation. In parallel with the economic, social and political factors, religion has gained increased significance in affecting consumer behaviour in emerging markets (Aoun \& Turnois, 2015). Marketers thus has been forced to formulate an effective strategy of specific branding and advertising techniques, such as focusing on particular problem and targeting at particular group of consumers, not to mention Muslim consumers. Trade liberalization as the result of the reforms of economic and politic has facilitated the emergence of Muslim consumers noticed as a promising market segment that aggressive to modern consumption yet sensitive to faith value (Nasr, 2009). It is known that manifestation of faith issue under the discussed area has constituted the occurrence of global halal market that expands the trend of halal in industries. The territory of halal industry has not been solely limited to food (Awan, Siddique, \& Haider, 2015), instead the concept of halal has covered nonfood industry, ranging from finance, insurance, tourism, travel, hospitality, fashion, to other various religiously inspired branded industries, including cosmetics that is booming recently. (Majid, Sabir, \& Ashraf, 2015; Ali, Halim, \& Ahmad, 2016;Jihan, Musa, \& Hasan 2016; Mahdzan, Zainudin \& Au, 2017; Bazazo et.al, 2017;; Amron, Umar, \& Mursid, 2018;).

Recently, in Indonesia as a Muslim majority nation, the issue of halal cosmetics has reached its top. It has been proven from the mushrooming of halal cosmetics industries that hype their commodities by claiming halal certification for their cosmetics products in their advertisements. Cosmetics manufacturers and marketers might have considered that advertisement could be one of the potential factors in increasing customers purchase intention.

Several previous researches have been conducted within the area of halal cosmetics market with respect to the consumption related variables. Ali, Halim, and Ahmad (2016) reviewed a number of past studies inspecting the behaviour of consumers in purchasing halal cosmetics. The findings suggest that research on halal cosmetic setting remains inconclusive since the fragmented models of research result in the diverse research outcomes. Majid, Sabir, and Ashraf (2015) pursued a quantitative research investigating the relationship of awareness, 
religious belief, and halal product certification towards consumer purchase intention of halal cosmetics in the geographical region of Pakistan. The result indicates that awareness, religious belief and halal certification positively influence the purchase intention of halal cosmetics brands. Jihan, Musa, and Hasan (2016) attempted to construct and validate the underlying factorial predictors of attitude among user and nonuser of halal skin care product. The result confirms four factors including spiritual congruence, spiritual intelligence, product image and product involvement as the strongest predictors of consumer attitude towards halal skin care products.

Taking a closer look at the aforementioned related studies, in spite of the fact that researches within the area of halal cosmetics are abound and compelling, the study of halal cosmetics still need more exploration since none of those related studies previously mentioned investigate advertisement as one of potential factor that might also influence the consumers behaviour towards halal cosmetics purchase intention. Thus, the present paper seeks to examine the verbal and visual elements of halal cosmetics advertising and the relationship of the multimodal elements to discover the attitude of advertising textual and visual markers in guiding the consumers to understand the cosmetic manufacturers' product advertised.The current paper adopts Cheong's (2004) Generic Structure Functional framework and Royce's (1998) Intersemiotic framework to scrutinise the data.Furthermore, religious discourse of persuasion as suggested by Adam (2017) is also used in interpreting the analysis.

\section{Method}

The current paper employs descriptive qualitative method. The data interpreted in this study is in the form of image accompanied with text in a digital cosmetic advertisement of Wardah, specifically the advertisement under the tag of \#HalaldariAwal. Denscombe (2010) stated that the use of words or images as the unit of analysis tends to be associated with qualitative research. The analysis of the data started from labelling and categorizing the elements of the advertisement based on Cheong (2004). Generic Structure Potential of advertisement as proposed by Cheong (2004) recognizes a harmonious combination of verbal text and visual image contained in the semiotic resource of the advertisement. The visual components consist of Lead, Display, and Emblem. While the verbal components are composed of Announcement, Enhancer, Tag, and Calland Visit Information.After deconstructing the visual and the verbal elements, each element is analysed and interpreted using Intersemiotic Complementary framework as suggested by Royce (1998) in order to understand the interaction between the verbal and the visual components. The framework comprises Repetition, Synonymy, Antonymy, Meronymy, Hyponymy, and Collocation. Additionally, religious discourse of persuasion as suggested by Adam (2017) is also used in interpreting the analysis.

\section{Discussion}

From the method outlined beforehand, the data that utilised for this current study is an advertisement of Wardah, specifically under the theme of \#HalaldariAwal. The visual and the verbal elements of this advertisement presenting the picture of the products completed the models is scrutinised. Cheong (2004) summarises that Generic Structure Potential of advertisement consists of Lead, (Display), Emblem, (Announcement), (Enhancer), (Tag), and (Call-and-Visit Information). Lead and Emblem are obligatory elements in advertisement, while other elements given within brackets are optional elements that may occur in the advertisement. To make it clearer to be analysed, the data is presented in Figure 1. 
Figure 1. Wardah \#HalaldariAwal Advertisement

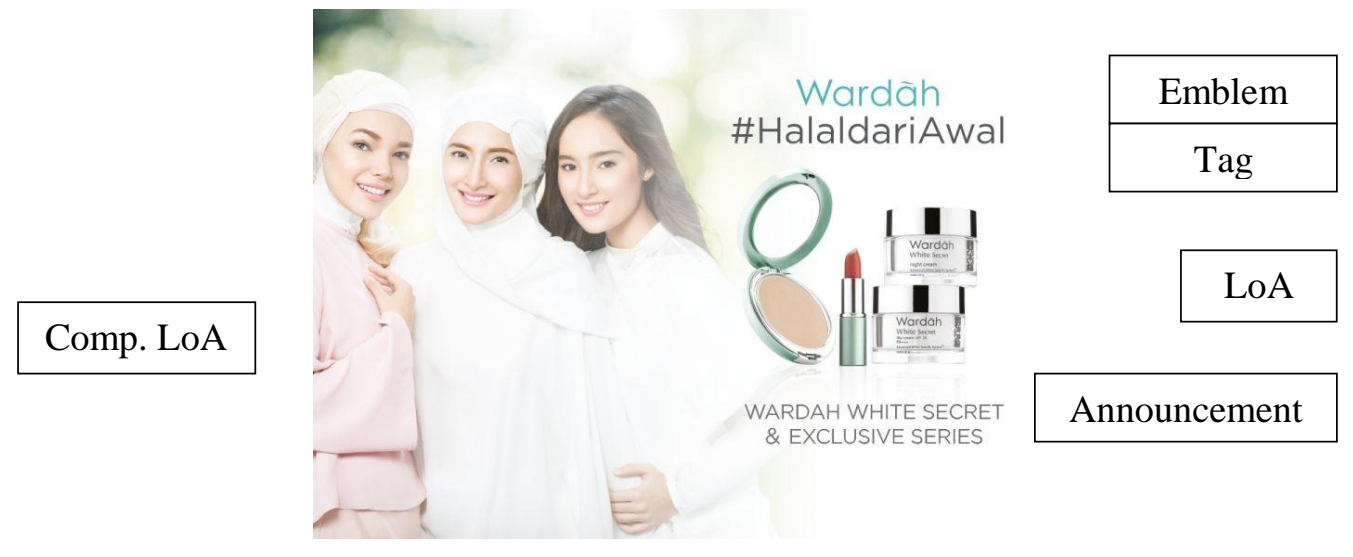

Noticing the advertisement, it has been identified that the advertisement contains Lead and Emblem which are known as the obligatory elements to be appeared in advertisement (Cheong, 2004). In this advertisement, the Lead occurs in the form of visual images and Emblem appears in the form of both visual image and verbal text. To add more, the Lead is composed of Locus of Attention and Complement of Locus of Attention. The Lead is explicitly and congruently presenting the promoted product i.e. cosmetics and skincare products. To be more specific, the products of cosmetics and skincare suggest that the Locus of Attention are lipstick and compact powder that represent cosmetic and day and night cream yang symbolise skin care. To add more, the three women placed next to the product shown as Complement of Locus of Attention portrayed a little bit in back to indicate a sense of insignificance or less significant since the focus is on the products. Those three women picture natural beauty of women that put simple make ups and wear simple outfits. The selection of white for the hijab and the blouse is identified to paint a picture of purity, and pink to convey positive information that facilitates the processing of emotionally congruent facial expressions showing happiness (Gill \& Le Bigot, 2014). Among the three women, the two are wearing hijab, this probably means that they are designed as the representation of Muslim as the majority population in Indonesia picturing the halal value. While the other one is not wearing hijab might presumably be intended to be the symbolism of the non-Muslim group that the advertisers try to cover. In other words, the composition of the models perhaps is set out to target all types of customers, means that everyone can consume this cosmetics regardless of the halal claim. Additionally, the logo of Wardah can be discerned as the Emblem of this advertisement. It is easily found in the form of the brand name of the product. Relevant to what is pinpointed by Kress and Van Leeuwen (1996), the Emblem is designed smaller in size compared to the Lead, yet located in noticeable location. In addition, it has also been recognised that the advertisement employs Announcement and Tag. Without too much extravagant slogan, Wardah emphasises the promotion of the product with announcing the variant of the product being promoted. \#HalaldariAwal is identified as the Tag. The phrase is a statement that reflects the claim that might become the motto of the factory.

With the assistance of Intersemiotic Framework proposed by Royce (1998), repetition or identical experiential meaning relationship of visual and verbal element of advertisement is seen in Wardah in the form of the advertisement's logo found in the Emblems that manifest in visual and repeated in verbal form. Additionally, there is also metonymy shown in the way that the models in the Complement of Locus of Attention wear hijab as part of Muslim identity that relates to Muslim faith value which strongly hold a belief of consuming halal product.

Overall, the elements of the advertisement of Wardah work together in synergy to influence general consumers purchase intention through particular religious value observed 
from the detail of the elements. Adam (2017) remarks that all items closely related to the basic purpose of religious communication can be labelled as religious discourse. The utilization of the verbal text emphasising the orientation of the manufacturer that halal is the religious value firmly held supported with the visual images accentuating the symbolization of what is perceived as halal through the depiction of women wearing hijab has been recognised as a religious discourse that exploited by the manufacturer and the advertiser to persuade the targeted consumer of their product. As a religious discourse, the advertisement of Wardah specifically the one with the tagline \#HalaldariAwal, convinces the targeted consumers of the veracity of the doctrine (i.e. halal value) through persuasion manifests in the form of multimodal advertisement as its pivotal instrument.

\section{Conclusion}

The broadening territory of halal from food to non-food industries has enhanced the hype of halal cosmetics industry that resulted in the competition and innovation in the halal cosmetics advertising. In persuading the consumers and influencing their purchase intention, faith value manifest in the form of halal value is enacted. In the case of Wardah, as one brand of cosmetics industry in Indonesia that makes commitment to produce halal cosmetics, religious discourse is demonstrated through the visual signs and the verbal markers of the advertisement to generate the religious ideology claimed.

\section{References}

Adam, M. 2017. Persuasion in religious discourse: Enhancing credibility in sermon titles and openings. Discourse and Interaction, 10(2), 5-25.

Ali, S., Halim, F., \& Ahmad N. 2016. The state of halal cosmetic research on consumer behaviour: A systematic review of the literature and future research directions. Journal of Marketing Management and Consumer Behaviour, 1(4), 40-51.

Amron, A., Usman, U., \& Mursid, A. 2018. Buying decision in the marketing of Sharia life insurance (evidence from Indonesia). Journal of Islamic Marketing.

Aoun, I., \& Turnois, L. 2015. Building holistic brands: an exploratory study of halalcosmetics. Journal of Islamic Marketing, 6(1), 109-132.

Awan, H. M., Siddique, A. N., \& Haider, Z. 2015. Factors affecting halal purchase intentionevidence from halal Pakistan's food sector. Management Research Review, 38(6), 640660.

Bazazo, I., Elyas, T., Awawdeh, L., Faroun, M. \& Qawasmeh, S. A. 2017. The impact of Islamic attributes of destination on destination loyalty via the mediating effect of tourist satisfaction. International Journal of Business Administration, 8(4), 65-78.

Cheong, Y. Y. 2004. The construal ideational meaning in print advertisement. In O'Halloran, K. L (ed.). Multimodal discourse analysis: systemic functional linguistics. London: Pinter Publisher.

Denscome, M. 2010. The good research guide; for small-scale social research project $4^{\text {th }}$ ed. Berkshire: Open University Press.

Gill, S., \& Le Bigot, L. 2014. Seeing life through positive-tinted glasses: Color-meaning Ascociations. Plos One, 9(8), 1-13.

Jihan, A., Musa, R., \& Hassan, F. 2016. Factorial validation predictors of attitude among user and nonuser of halal skin care product. Procedia Economics and Finance, 37, $239-244$.

Kress, G., \& Van Leeuwen, T. 1996. Reading images: The grammar of visual design. London: Routledge.

Mahdzan, N. S., Zainudin, R., \& Au, S. F. 2017. The adoption of Islamic banking services in Malaysia. Journal of Marketing, 8(3), 496-512.

Majid, M. B., Sabir, I., \& Ashraf, T. 2015. Consumer purchase intention towards halal cosmetics \& personal care products in Pakistan. Global Journal of Research in Business and Management, 1(1), 47-55.

Nasr, V. 2009. Forces of Fortune. New York: Free Press. 
Royce, T. 1998. Synergy on the page: exploring intersemiotic complementarity in page-based multimodal texts: perceptual. JASF Occasional Paper, 1(1), 25-49. 